\title{
Good Governance: A Step towards Promoting Positive Attitude and Enhancing Productivity in the Civil Service
}

\author{
Dr. Bala I. Sambo \& Ato Shoa Jemal
}

\section{Abstract}

This is a research about good governance in the civil service. Five federal organizations served as research population: Ministry for Capacity Building, Ministry of Revenue, Federal Civil Service Agency, Ethiopian Civil Service College, and Ethiopian Management Institute. Fifty-six (56) respondents served as research sample. The research was conducted through the use of a research instrument (opinionnaire). Percentage (\%) and Chi square $\left(X^{2}\right)$ were used as statistical tools. It was found out that reform program pays equal attention to all citizens; financial regulations are violated in Government expenditure; service delivery is poor in the Civil Service; unethical practices do exist in Civil Service; top management system is poor; and Civil Service (HR) is ineffective. Based on the research findings it was recommended that Civil servants need a lot more of education, training and development.

\section{General Background}

The United Nations Development Programme (1999) defines Governance as the exercise of political, economic and administrative authority in the management of the affairs of a mechanism, processes and institutions through which citizens and groups articulate their interest, mediate their differences, and exercise their legal rights and obligations.

Good governance is used to describe the inter-play of best practices in the governance of a nation. The concept 
Good Governance: A Step towards Promoting Positive Attitude...

characterizes issues of performance of best practices in the management of the country's political, economic and social resources to enhance human progress, social well being and sustainable development. The purpose of good government is to create a conducive climate for political and socio-economic development and to increase the efficiency and effectiveness of development programmes.

The main features of good governance include promotion of open market, friendly and competitive economies, support for democratization and improvement of human rights records. The World Bank (1989) identifies the essential features of good governance as: legitimacy of government; accountability of political and official elements of government; competence of government to formulate policies and deliver service; and respect for human rights and law. Legitimacy government refers to the degree of democratization in the polity while accountability of political and official elements of government refers to issues of press freedom, transparent decision-making and accountability mechanisms.

Government is an open system with inputs and outputs from both its internal and external environment. Changes in the world's economic, political and social systems have brought unprecedented is the pivot around which other factors of development revolve, particularly as development is no longer measured solely by per capital income. Other indices of human development include equity in the development of the citizenry (both men and women), co-operation among all identifiable groups, security and sustainability, particularly for the younger generation.

Good governance ensures that political, social and economic choices or decisions are made on the basis of broad consensus in the society through elected representatives. Good governance should, among other things, be 
participative, transparent, equitable and accountable. It should enhance high-level institutional effectiveness and economic growth. The rule of law must prevail, complemented by a politically stable environment for the formulation and implementation of government policies. Good governance ensure co-operation between the political class and the administrative class for the delivery of high quality services needed for sustainable development and growth. Good government presumes the primacy of laws and due process, the independency of the judiciary, the separation of powers as between the executive and the legislative and political accountability (Sambo, 2004).

\section{Good Governance in the Civil Service}

The civil service is a mini-society in the state, which as heterogeneous body of individuals who translate all government plans, projects and programmes into implementable actions. A civil servant is, therefore, a government employee who is on permanent appointment in federal or regional government institutions. Governance in the civil service connotes that civil servants exhibit high sense of responsibility, which is enshrined in the reform programme of the federal government. Good governance as far as the civil service is concerned encompasses ethics, customer service delivery, human resource, top management system and expenditure management and control.

Good Governance is evaluated by values such as responsive to the demand of citizens, transparency, accountability, effectiveness and efficiency which are fundamental features of the civil service. The dictates of democratic governance and the impact of globalization suggest the following essential features of good government: 
Good Governance: A Step towards Promoting Positive Attitude...

i. legitimate distinction between politics and civil service;

ii. professionalisation of the civil service.

iii. right staffing of the civil service;

iv. accountability and transparency of political and bureaucratic appointees of government;

v. respect for and enforcement of fundamental human rights(freedom of expression and association etc);

vi. elaborate citizen participation in the governance process;

vii. collaboration of civil service with the private sector in governance;

viii. sustainable civil service, participating in public affairs under the rule of law;

In this study, good governance will be viewed from the perspective of the federal government. Good governance in the civil service would entail the entire reform programme of the federal government. That is, good governance in the civil service connotes positive results in all the five reform programmes. In other words, positive outcomes of the reform programme would connote good governance in the civil service and negative outcomes of the reform programmes would connote poor governance in the civil service.

The law can and should be used as a force for social change when values and norms in a society are undergoing change. The enforcement of codes of law should be the cornerstone of any ethics infrastructure. Nobody should be seen as being above the law or favoured by the law.

The intent of transparency in government is to ensure that governmental decision-making and implementation take place according to rules and regulations that are known and under stood by the affected persons and citizens. Transparency assures accountability in the conduct of government business. Viable socio- economic development 
can only be achieved if good governance priorities are enforced. Some of the issues that good governance should translate into sustainable development from the socioeconomic perspective are: enlargement of individual and group participation in political and socio-economic activities; centrality of the populace in the formulation of policies and efficiently managed public service.

\section{Constraints against Good Governance}

The concept of governance has gained particular significance in the literature on African politics as a result of World Bank (1998) identifying the crisis on the African continents as one of good governance. In the discussion on good governance in Africa, the focus has been on African public administrations. The term "public administration" is used here in a generic sense to refer to agencies an organizations funded wholly or partially through monies voted by the appropriate legislative institution, such as civil service ministries, public corporations, the security apparatus, the defense force, central and local administrative structures, etc. which constitute the main operational machinery of the state. The focus here in on the civil service. According to Ayeni (2000) constraints to good governance in the civil service could include:

- The shortage of skilled manpower

- General over loading of the staff positions;

- Growth of ethnic sentiments and conflicts

- Inter-generational conflict

- Poor work ethics within the civil service

- Flexibility in the performance of tasks

- Plagued by role confusion

- Inadequate coordination of their various activities 
Good Governance: A Step towards Promoting Positive Attitude...

- Low planning capacity

- Political instability

- Excessive bureaucratic politics

Contemporary thinking about good governance has inevitably helped re-focus attention on the significance of governments even though they are now expected to do things differently from the past. Commenting on this role reconception, the World Bank maintains that governments must today play a key role in the provision of public good. They establish the rules that make markets work efficiently and more problematically, they correct revenues and produce the public goods. This in turn requires systems of accountability, adequate and reliable information and efficiency in resource management and the delivery of public services. This is a vivid observation about the interlocking relationship between the end and means of good governance.

\section{Objective of the Study}

The main objective of the study is to find out the extent to which the government reform programmes have been put into practice. Specifically, the study aims at finding out the following:

1. Whether the reform programmes are focused on the generality of the citizenry

2. Whether the civil service is effective or not

3. whether financial regulations are observed in government expenditure or not

4. Whether service delivery is customer based or not

5. Whether unethical practices still exist in the civil service or not

6. Whether top management system is effective or not 


\section{Research Questions}

In order to address the stated objectives the following questions have been postulated:

1. What is the focus of the reform programme?

2. Is the civil service effective?

3. Are financial regulations violated in government expenditure?

4. What is the state of service delivery in the civil service?

5. Do unethical practices exist in the civil service?

6. What is the state of top management system?

\section{Methodology}

In this study, 56 respondents served as subjects. The sample was drawn from Ministry for Capacity Building, Ministry of Revenue, Federal Civil Service Agency, Ethiopian Civil Service College, and Ethiopian Management Institute. The respondents included top management, middle management, low management and junior staffs. Judgmental sampling technique was used to draw the research respondents. An instrument (opinionnaire) was used to collect data. Chi square $\left(X^{2}\right)$ and percentage (\%) were used to analyze the data.

\section{Data Analysis, Presentation and Interpretation}

Table 1: Response by Organization

\begin{tabular}{|l|c|c|}
\hline ORGANIZATION & Frequencies & $\begin{array}{l}\text { Percentage } \\
(\%)\end{array}$ \\
\hline Ministry for Capacity Building & 6 & 10.7 \\
\hline Ministry of Revenue & 22 & 39.3 \\
\hline Federal Civil Service Agency & 8 & 14.3 \\
\hline Ethiopian Civil Service College & 10 & 17.9 \\
\hline Ethiopian Management Institute & 10 & 17.9 \\
\hline TOTAL & 56 & 100.1 \\
\hline
\end{tabular}


Good Governance: A Step towards Promoting Positive Attitude...

In table 1 , it could be observed that six (6) respondents representing nearly eleven percent. (10.7\%) came from Ministry for Capacity Building; twenty-two (22) respondents representing a little over thirty-nine percent (39.3\%) came from the Ministry of Revenue; eight (8) respondents representing a little over fourteen percent $(14.3 \%)$ came from Federal Civil Service Agency; ten (10) respondents representing nearly eighteen percent $(17.9 \%)$ came from Ethiopian Civil Service College and ten (10) respondents representing nearly eighteen percent $(17.9 \%)$ came from Ethiopian Management Institute.

Table 2: Response by Status

\begin{tabular}{|l|c|c|}
\hline STATUS & Frequencies & Percentage (\%) \\
\hline Top Manager & 11 & 19.6 \\
\hline Middle Manager & 15 & 26.8 \\
\hline Low Manager & 12 & 21.4 \\
\hline Junior Staff & 18 & 32.1 \\
\hline TOTAL & 56 & 99.9 \\
\hline
\end{tabular}

In table 2, it could be observed that eleven (11) respondents representing nearly twenty percent (19.6\%) were top managers; fifteen (15) respondents representing nearly twenty-seven percent (26.8\%) were middle managers; twelve respondents (12) representing a little over twenty-one percent $(21.4 \%)$ were low mangers; and eighteen (18) respondents representing a little over thirty-two percent (32.1\%) were junior staff.

Table 3: Focus of the Reform Program

\begin{tabular}{|c|l|l|l|l|c|c|}
\hline OPINION & O & $\mathbf{E}$ & $\mathbf{O}-\mathbf{E}$ & $\mathbf{( O - E ) 2}$ & $\frac{(\mathbf{O}-\mathbf{E})^{2}}{\mathbf{E}}$ & \% \\
\hline SA & 11 & 11.2 & -0.2 & 0.04 & 0.0 & 19.6 \\
\hline A & 16 & 11.2 & 4.8 & 23.04 & 2.1 & 28.6 \\
\hline NO & 9 & 11.2 & -2.2 & 4.84 & 0.4 & 16.1 \\
\hline D & 10 & 11.2 & -1.2 & 1.44 & 0.1 & 17.9 \\
\hline SD & 10 & 11.2 & -1.2 & 1.44 & 0.1 & 17.9 \\
\hline \multicolumn{7}{|c|}{$X^{2}$} \\
2.7 & 100.1 \\
\hline
\end{tabular}


$\mathrm{X}^{2}=2.7 ; \quad \mathrm{df}=4 ; \quad \mathrm{CV}=7.78 ; \quad \mathrm{P}<.05$

$\mathrm{H}_{0}$ : Reform Program Pays Equal Attention to all Citizens

$\mathrm{H}_{1}$ : Reform Program Pays More Attention to the Elites

In table 3, it could be observed that eleven (11) respondents representing nearly twenty percent (20\%) strongly agreed that the reform program targets elites only; sixteen (16) respondents representing nearly twenty-nine percent $(28.6 \%)$ agreed that the reform program targets elites only; zero (0) respondents representing zero percent (0\%) did not state whether the reform program targets elites or not; nineteen (19) respondents representing nearly thirty-four percent $(34 \%)$ disagreed that the reform program targets elites only; and ten (10) respondents representing nearly eighteen percent $(17.9 \%)$ strongly disagreed that the reform program targets elites only. Although, majority of respondents agreed that the reform program targets elites only, it is not found to be statistically significant. The chi square $\left(\mathrm{X}^{2}=2.7 ; \mathrm{df}=4 ; \mathrm{CV}=7.78 ; \mathrm{P}>.050\right)$ stipulates that we accept the null hypothesis which states that the reform program pays equal attention to all Citizens; and reject the alternate hypothesis which states that reform program pays more attention to elites. We therefore conclude that the reform program pays equal attention to all citizens. This means that the reform programme is adequately publicized.

Table 4: The Status of (Human Resource ineffectiveness) the Civil Service

\begin{tabular}{|c|c|c|c|c|c|c|}
\hline OPINION & $\mathbf{O}$ & $\mathbf{E}$ & $\mathbf{O}-\mathbf{E}$ & $\mathbf{( \mathbf { O } - \mathbf { E } ) \mathbf { 2 }}$ & $\frac{\mathbf{( \mathbf { O } - \mathbf { E } ) ^ { 2 }}}{\mathbf{E}}$ & $\mathbf{\%}$ \\
\hline $\mathrm{SA}$ & 10 & 11.2 & -1.2 & 1.44 & 0.1 & 17.9 \\
\hline A & 30 & 11.2 & 18.8 & 353.44 & 31.6 & 53.6 \\
\hline NO & 5 & 11.2 & -6.2 & 38.44 & 3.4 & 8.9 \\
\hline D & 7 & 11.2 & -4.2 & 17.64 & 1.6 & 12.5 \\
\hline SD & 4 & 11.2 & -7.2 & 51.84 & 4.6 & 7.1 \\
\hline$X^{2}$ & \multicolumn{7}{|c|}{43.3} & 100.0 \\
\hline
\end{tabular}


Good Governance: A Step towards Promoting Positive Attitude...

$X^{2}=43.3 ; \quad$ df $=4 ; \quad C V=7.78 ; \quad P<.05$

$\mathrm{H}_{0}$ : Civil Service is not ineffective

$\mathrm{H}_{1}$ : Civil Service in Ineffective

In table 4 , it could be seen that ten (10) respondents representing nearly eighteen percent $(17.9 \%)$ strongly agreed that the civil service is ineffective; thirty (30) respondents representing nearly fifty-four percent $(53.6 \%)$ agreed that the civil service is ineffective; five (5) respondents representing nearly nine percent $(8.9 \%)$ did not state whether the civil service is ineffective or not; seven (7) respondents representing nearly thirteen percent $(12.5 \%)$ disagreed that the civil service is ineffective; and four (4) respondents representing a little over seven percent (7.1\%) strongly disagreed that the civil service is ineffective. Majority of respondents agreed that the civil service is ineffective. This is found to be statistically significant $\left(X^{2}=43.3 ; \quad d f=4 ; \quad C V=\right.$ 7.78; $P<.050)$ stipulates that we reject the null hypothesis which states that the Civil Service is not ineffective; and accept the alternate hypothesis which states that Civil Service is ineffective. We therefore conclude that the Civil Service is ineffective. This connotes the need to educate, train and develop the civil service.

Table 5: The Status of Top Management System

\begin{tabular}{|c|c|c|c|c|c|c|}
\hline OPINION & $\mathbf{O}$ & $\mathbf{E}$ & $\mathbf{O}-\mathbf{E}$ & $\mathbf{( \mathbf { O } - \mathbf { E } ) 2}$ & $\frac{(\mathbf{O}-\mathbf{E})^{\mathbf{2}}}{\mathbf{E}}$ & $\mathbf{\%}$ \\
\hline SA & 10 & 11.2 & -1.2 & 1.44 & 0.1 & 17.9 \\
\hline A & 19 & 11.2 & 7.8 & 60.84 & 0.8 & 33.9 \\
\hline NO & 11 & 11.2 & -0.2 & 0.04 & 0.0 & 19.6 \\
\hline D & 11 & 11.2 & -0.2 & 0.04 & 0.0 & 19.6 \\
\hline SD & 5 & 11.2 & -6.2 & 38.44 & 3.4 & 8.9 \\
\hline$X^{2}$ \\
13.5
\end{tabular}

$\mathrm{X}^{2}=13.5 ; \quad \mathrm{df}=4 ; \quad \mathrm{CV}=7.78 ; \quad \mathrm{P}<.05$

$\mathrm{H}_{\mathrm{o}}$ : Top Management System is not poor

$\mathrm{H}_{1}$ : Top Management System is Poor 
In table 5, it could be seen that ten 10) respondents representing nearly eighteen percent (17.9\%) strongly agreed that the Top Management System is poor; nineteen (19) respondents representing nearly thirty-four percent (33.9\%) agreed that the Top Management System is poor; eleven (11) respondents representing nearly twenty percent (19.6\%) did not state whether the Top Management System is poor or not; eleven (11) respondents representing nearly twenty percent $(19.6 \%)$ disagreed that the Top Management System is poor; and five (5) respondents representing nearly nine percent (8.9\%) strongly disagreed that the Top Management System is poor. Majority of respondents agreed that the civil service is ineffective. This is found to be statistically significant $\left(X^{2}=\right.$ 13.3; $\quad$ df $=4 ; \quad C V=7.78 ; \quad P<.050)$ stipulates that we reject the null hypothesis which states that the Top Management System is not poor; and accept the alternate hypothesis which states that Top Management System is Poor. We therefore conclude that the Top Management System is poor. This means that there is the need for educating, training and developing the Top Management in the civil service.

Table 6: Expenditure Management Vs Financial Regulations

\begin{tabular}{|c|c|c|c|c|c|c|}
\hline OPINION & $\mathbf{O}$ & $\mathbf{E}$ & $\mathbf{O}-\mathbf{E}$ & $\mathbf{( O - E ) 2}$ & $\frac{(\mathbf{O}-\mathbf{E})^{2}}{\mathbf{E}}$ & \% \\
\hline SA & 9 & 11.2 & -2.2 & 4.84 & 0.4 & 16.1 \\
\hline A & 11 & 11.2 & -0.2 & 0.04 & 0.0 & 19.6 \\
\hline NO & 19 & 11.2 & 7.8 & 60.84 & 5.4 & 33.9 \\
\hline D & 12 & 11.2 & 0.8 & 0.64 & 0.1 & 21.4 \\
\hline SD & 5 & 11.2 & -6.2 & 38.44 & 3.4 & 8.9 \\
\hline \multicolumn{7}{|c|}{$X^{2}$} \\
\hline$X^{2}=9.3 ;$ & df $=4 ; \quad$ CV $=7.78 ; \quad P<.05$ \\
\hline
\end{tabular}


Good Governance: A Step towards Promoting Positive Attitude...

$\mathrm{H}_{\mathrm{o}}$ : Financial Regulations are not violated in Government Expenditure

$\mathrm{H}_{1}$ : Financial Regulations are violated in Government Expenditure

In table 6, it could be observed that nine (9) respondents representing a little over sixteen percent $(16.1 \%)$ strongly agreed that financial regulations are violated in government expenditure; eleven (11) respondents representing nearly twenty percent (19.6\%) agreed that financial regulations are violated in government expenditure; nineteen respondents representing nearly thirty-four percent (33.9\%) did not state whether financial regulations are violated in government expenditure or not; twelve (12) respondents representing a little over twenty-one percent (21.4\%) disagreed that financial regulations are violated in government expenditure; and five (5) respondents representing nearly nine percent $(8.9 \%)$ strongly disagreed that financial regulations are violated in government expenditure. Majority of respondents agreed that the civil service is ineffective. This is found to be statistically significant $\left(X^{2}=9.3 ; \quad\right.$ df $=4 ; \quad C V=$ 7.78; $\quad P<.050)$ stipulates that we reject the null hypothesis which states that expenditure management System is not violated; and accept the alternate hypothesis which states that expenditure management system is violated. We therefore conclude that Financial Regulations are violated in Government Expenditure. This uncovers the need for training and development in the civil service.

Table 7: The State of Service Delivery in the Civil Service

\begin{tabular}{|c|c|c|c|c|c|c|}
\hline OPINION & $\mathbf{O}$ & $\mathbf{E}$ & $\mathbf{O}-\mathbf{E}$ & $\mathbf{( O - E ) 2}$ & $\frac{(\mathbf{O}-\mathbf{E})^{2}}{\mathbf{E}}$ & \% \\
\hline SA & 14 & 11.2 & 2.8 & 7.84 & 0.7 & 25.0 \\
\hline A & 26 & 11.2 & 14.8 & 219.04 & 19.6 & 46.4 \\
\hline NO & 2 & 11.2 & -9.2 & 84.64 & 7.6 & 3.6 \\
\hline D & 9 & 11.2 & -2.2 & 4.84 & 0.4 & 16.1 \\
\hline SD & 5 & 11.2 & -6.2 & 38.44 & 3.4 & 8.9 \\
\hline$X^{2}$ & 31.7 & \multicolumn{5}{|l}{} \\
\hline
\end{tabular}


$\mathrm{X}^{2}=31.7 ; \quad \mathrm{df}=4 ; \quad \mathrm{CV}=7.78 ; \quad \mathrm{P}<.05$

$\mathrm{H}_{\mathrm{o}}$ : Service Delivery is not poor

$\mathrm{H}_{1}$ : Service Delivery is Poor

In table 7, it could be observed that fourteen (14) respondents representing twenty-five percent $(25.0 \%)$ strongly agreed that service delivery is poor in the civil service; twenty-six (26) respondents representing a little over forty-six percent $(46.4 \%)$ agreed that service delivery is poor in the civil service; nineteen (19) respondents representing nearly four percent $(3.6 \%)$ did not state whether service delivery is poor in the civil service or not; nine (9) respondents representing a little over sixteen percent $(16.1 \%)$ disagreed that service delivery is poor in the civil service; and five (5) respondents representing nearly nine percent $(8.9 \%)$ strongly disagreed that service delivery is poor in the civil service. Majority of respondents agreed that the civil service is ineffective. This is found to be statistically significant $\left(\mathrm{X}^{2}=31.7 ; \mathrm{df}=4 ; \quad \mathrm{CV}=\right.$ 7.78; $\quad P<.050$ ) which stipulates that we reject the null hypothesis which states that service delivery is not poor in the civil service; and accept the alternate hypothesis which states that service delivery is poor in the civil service. We therefore conclude that service delivery is poor in the civil service. This connotes that civil servants do not measure up to the expectations of the public; which further indicates the need for civil servants to be exposed to more and more training and development in service delivery. 
Good Governance: A Step towards Promoting Positive Attitude...

Table 8: Ethics in the Civil Service

\begin{tabular}{|c|c|c|c|c|c|c|}
\hline OPINION & $\mathbf{O}$ & $\mathbf{E}$ & $\mathbf{O}-\mathbf{E}$ & $\mathbf{( O - E ) 2}$ & $\frac{(\mathbf{O}-\mathbf{E})^{\mathbf{2}}}{\mathbf{E}}$ & $\mathbf{\%}$ \\
\hline $\mathrm{SA}$ & 9 & 11.2 & -2.2 & 4.84 & 0.4 & 16.1 \\
\hline $\mathrm{A}$ & 25 & 11.2 & 13.8 & 190.44 & 17.0 & 44.6 \\
\hline $\mathrm{NO}$ & 6 & 11.2 & -5.2 & 27.04 & 2.4 & 10.7 \\
\hline $\mathrm{D}$ & 10 & 11.2 & -1.2 & 1.44 & 0.1 & 17.9 \\
\hline $\mathrm{SD}$ & 6 & 11.2 & -5.2 & 27.04 & 2.4 & 10.7 \\
\hline $\mathrm{X}^{2}$ & \multicolumn{7}{|c|}{22.3} & 100.0 \\
\hline
\end{tabular}

$\mathrm{X}^{2}=22.3 ; \quad \mathrm{df}=4 ; \quad \mathrm{CV}=7.78 ; \quad \mathrm{P}<.05$

$\mathrm{H}_{\mathrm{o}}$ : Unethical Practices do not Exist in Civil Service

$\mathrm{H}_{1}$ : Unethical Practices Exist in Civil Service

In table 8, it could be observed that (9) respondents representing a little over sixteen percent $(16.1 \%)$ strongly agreed that unethical practices exist in civil service; twentyfive (25) respondents representing nearly forty-five percent $(44.6 \%)$ agreed that unethical practices exist in civil service; six (6) respondents representing nearly eleven percent $(10.7 \%)$ did not state whether unethical practices exist in civil service or not; ten (10) respondents representing nearly eighteen percent $(17.9 \%)$ disagreed that unethical practices exist in civil service; and six (6) respondents representing nearly eleven percent $(10.7 \%)$ strongly disagreed that unethical practices exist in civil service. Majority of respondents agreed that unethical practices do exist in civil service. This is found to be statistically significant $\left(X^{2}=22.3\right.$; $\mathrm{df}=4 ; \quad \mathrm{CV}=7.78 ; \quad \mathrm{P}<.050$ ) which stipulates that we reject the null hypothesis which states that unethical practices do not exist in civil service; and accept the alternate hypothesis which states that unethical practices do exist in civil service in the civil service. We therefore conclude that unethical practices do exist in civil service. This implies that civil servants need to be reminded of their moral responsibility. 
Table 9: Top Management Vs Lack of Training

\begin{tabular}{|c|c|c|c|c|c|c|}
\hline OPINION & $\mathbf{O}$ & $\mathbf{E}$ & $\mathbf{O}-\mathbf{E}$ & $\mathbf{( O - E ) 2}$ & $\frac{(\mathbf{O}-\mathbf{E})^{2}}{\mathbf{E}}$ & $\mathbf{\%}$ \\
\hline $\mathrm{SA}$ & 9 & 11.2 & -2.2 & 4.84 & 0.4 & 16.1 \\
\hline $\mathrm{A}$ & 21 & 11.2 & 9.8 & 96.04 & 8.6 & 37.5 \\
\hline NO & 7 & 11.2 & -2.8 & 7.8 & 0.6 & 12.5 \\
\hline $\mathrm{D}$ & 12 & 11.2 & 0.8 & 0.64 & 0.1 & 21.4 \\
\hline $\mathrm{SD}$ & 7 & 11.2 & -4.2 & 17.64 & 1.6 & 12.5 \\
\hline $\mathrm{X}^{2}$ \\
11.3
\end{tabular}

$\mathrm{X}^{2}=11.3 ; \quad \mathrm{df}=4 ; \quad \mathrm{CV}=7.78 ; \quad \mathrm{P}<.05$

$\mathrm{H}_{\mathrm{o}}$ : Top Management System is not affected by Lack of

Training

$\mathrm{H}_{1}$ : Top Management System is affected by Lack of Training

In table 9, it could be observed that nine (9) respondents representing a little over sixteen percent (16.1\%) strongly agreed that top management system is affected by lack of training; twenty-one (21) respondents representing nearly thirty-eight percent (37.5\%) agreed that top management system is affected by lack of training; seven (7) respondents representing nearly thirteen percent (12.5\%) did not state whether top management system is affected by lack of training or not; twelve (12) respondents representing a little over twenty-one percent $(21.4 \%)$ disagreed that top management system is affected by lack of training; and seven (7) respondents representing nearly thirteen percent (12.5\%) strongly disagreed that top management system is affected by lack of training. Majority of respondents agreed that the civil service is affected by lack of training. This is found to be statistically significant $\left(X^{2}=11.3 ; \quad d f=4 ; \quad C V=7.78 ; \quad P<\right.$ .050) which stipulates that we reject the null hypothesis which states that top management system is not affected by lack of 
Good Governance: A Step towards Promoting Positive Attitude... training; and accept the alternate hypothesis which states that top management system is affected by lack of training. We therefore conclude that top management system is affected by lack of training. This underscores the need for more and more training for the civil servants.

Table 10: Top Management Vs Lack of Proper Attitude

\begin{tabular}{|c|c|c|c|c|c|c|}
\hline OPINION & $\mathbf{O}$ & $\mathbf{E}$ & $\mathbf{O}-\mathbf{E}$ & $\mathbf{( O - E ) 2}$ & $\frac{(\mathbf{O}-\mathbf{E})^{\mathbf{2}}}{\mathbf{E}}$ & $\mathbf{\%}$ \\
\hline SA & 11 & 11.2 & -0.2 & 0.04 & 0.0 & 19.6 \\
\hline A & 27 & 11.2 & 15.8 & 249.64 & 22.3 & 48.2 \\
\hline NO & 6 & 11.2 & -5.2 & 27.04 & 2.4 & 10.7 \\
\hline D & 6 & 11.2 & -5.2 & 27.04 & 2.4 & 10.7 \\
\hline SD & 6 & 11.2 & -5.2 & 27.04 & 2.4 & 10.7 \\
\hline$X^{2}$ \\
29.5
\end{tabular}

$\mathrm{X}^{2}=29.5 ; \quad \mathrm{df}=4 ; \quad \mathrm{CV}=7.78 ; \quad \mathrm{P}<.05$

$\mathrm{H}_{0}$ : Top Management System is not Affected by Lack of Proper

Attitude

$\mathrm{H}_{1}$ : Top Management System is Affected by Lack of Proper Attitude

In table 10, it could be observed that eleven (11) respondents representing nearly twenty percent $(19.6 \%)$ strongly agreed that top management system is affected by lack of proper attitude; twenty-seven (27) respondents representing a little over forty-eight percent (48.2\%) agreed that top management system is affected by lack of proper attitude; six respondents representing nearly eleven percent $(10.7 \%)$ did not state whether top management system is affected by lack of proper attitude or not; six (6) respondents representing nearly eleven percent $(10.7 \%)$ disagreed that top management system is affected by lack of proper attitude; and six (6) respondents representing nearly eleven percent $(10.7 \%)$ strongly disagreed that top management system is 
affected by lack of proper attitude. Majority of respondents agreed that top management system is affected by lack of proper attitude. This is found to be statistically significant $\left(X^{2}=29.5 ; \quad d f=4 ; \quad C V=7.78 ; \quad P<.050\right)$ which stipulates that we reject the null hypothesis which states that top management system is not affected by lack of proper attitude; and accept the alternate hypothesis which states that top management system is affected by lack of proper attitude. We therefore conclude that top management system is affected by lack of proper attitude. This suggests the need to expose top management to training and development that will help reshape their attitude.

Table 11: Civil Service Ethics Vs Not Being Practiced

\begin{tabular}{|c|c|c|c|c|c|c|}
\hline OPINION & $\mathbf{O}$ & $\mathbf{E}$ & $\mathbf{O}-\mathbf{E}$ & $\mathbf{( O - E ) 2}$ & $\frac{(\mathbf{O}-\mathbf{E})^{\mathbf{2}}}{\mathbf{E}}$ & $\mathbf{\%}$ \\
\hline SA & 15 & 11.2 & 3.8 & 14.44 & 1.3 & 26.8 \\
\hline A & 26 & 11.2 & 14.8 & 219.04 & 19.6 & 46.4 \\
\hline NO & 3 & 11.2 & -8.2 & 67.24 & 6.0 & 5.4 \\
\hline D & 6 & 11.2 & -5.2 & 27.04 & 2.4 & 10.7 \\
\hline SD & 6 & 11.2 & -5.2 & 27.04 & 2.4 & 10.7 \\
\hline$X^{2}$ \\
31.7
\end{tabular}

$\mathrm{X}^{2}=31.7 ; \quad$ df $=4 ; \quad$ CV $=7.78 ; \quad \mathrm{P}<.05$

$\mathrm{H}_{\mathrm{o}}$ : Ethics is more of practice than theory in the civil service $\mathrm{H}_{1}$ : Ethics is more of theory than practice in the civil service

In table 11, it could be observed that fifteen (15) respondents representing nearly twenty-seven percent $(26.8 \%)$ strongly agreed that ethics is more of theory than practice in the civil service; twenty-six (26) respondents representing a little over forty-six percent (46.4\%) agreed that ethics is more of theory than practice in the civil service ethics is more of theory than practice in the civil service; three (3) 
Good Governance: A Step towards Promoting Positive Attitude...

respondents representing a little over five percent (5.4\%) did not state whether ethics is more of theory than practice in the civil service or not; six (6) respondents representing nearly eleven percent $(10.7 \%)$ disagreed that ethics is more of theory than practice in the civil service; and six (6) respondents representing nearly eleven percent (10.7\%) strongly disagreed that ethics is more of theory than practice in the civil service. Majority of respondents agreed that Ethics is more of theory than practice in the civil service. This is found to be statistically significant $\quad\left(X^{2}=31.7 ; d f=4 ; \quad C V\right.$ $=7.78 ; \quad P<.050$ ) which stipulates that we reject the null hypothesis which states that ethics is more of practice than theory in the civil service; and accept the alternate hypothesis which states that ethics is more of theory than practice in the civil service. We therefore conclude that ethics is more of theory than practice in the civil service. This means that civil servants operate at variance with the society. It also means that the civil servants require training and development in ethics with a view of changing their attitude.

Table 12: Societal Ethics Vs Not Being Practiced

\begin{tabular}{|c|c|c|c|c|c|c|}
\hline OPINION & 0 & E & O-E & $(O-E) 2$ & $\frac{(O-E)^{2}}{E}$ & $\%$ \\
\hline SA & 10 & 11.2 & -1.2 & 1.44 & 0.1 & 17.9 \\
\hline A & 10 & 11.2 & -1.2 & 1.44 & 0.1 & 17.9 \\
\hline $\mathrm{NO}$ & 10 & 11.2 & -1.2 & 1.44 & 0.1 & 17.9 \\
\hline D & 16 & 11.2 & 4.8 & 23.04 & 2.1 & 28.6 \\
\hline SD & 10 & 11.2 & -1.2 & 1.44 & 0.1 & 17.9 \\
\hline $\begin{array}{l}X^{2} \\
2.5\end{array}$ & & & & & & 100.0 \\
\hline
\end{tabular}

$\mathrm{X}^{2}=2.5 ; \quad \mathrm{df}=4 ; \quad \mathrm{CV}=7.78 ; \quad \mathrm{P}>.05$

$\mathrm{H}_{\mathrm{o}}$ : Ethics is more of practice than theory in the society

$\mathrm{H}_{1}$ : Ethics is more of theory than practice in the society

In table 12, it could be observed that ten (10) respondents representing nearly eighteen percent (17.9\%) strongly agreed that ethics is more of theory than practice in the society; twelve ten (10) respondents representing nearly 
eighteen percent (17.9\%) agreed that ethics is more of theory than practice in the society; ten (10) respondents representing nearly eighteen percent $(17.9 \%)$ did not state whether ethics is more of theory than practice in the society or not; sixteen (16) respondents representing nearly twenty-nine percent $(28.6 \%)$ disagreed that ethics is more of theory than practice in the society; ten (10) respondents representing nearly eighteen percent $(17.9 \%)$ strongly disagreed that ethics is more of theory than practice in the society. Majority of respondents agreed that ethics is more of practice than theory in the society. This is found to be statistically significant $\left(X^{2}\right.$ $=2.5 ; \mathrm{df}=4 ; \quad \mathrm{CV}=7.78 ; \mathrm{P}>.050$ ) which stipulates that we accept the null hypothesis which states that ethics is more of practice than theory in the society; and reject the alternate hypothesis which states that ethics is more of theory than practice in the society. We therefore conclude that ethics is more of practice than theory in the society. This signifies the fact that the society values ethical behaviour.

Table 13: Service Delivery Vs Lack of Public Awareness

\begin{tabular}{|c|c|c|c|c|c|c|}
\hline OPINION & $\mathbf{O}$ & $\mathbf{E}$ & $\mathbf{O}-\mathbf{E}$ & $\mathbf{( \mathbf { O } - \mathbf { E } ) \mathbf { 2 }}$ & $\frac{(\mathbf{O}-\mathbf{E})^{\mathbf{2}}}{\mathbf{E}}$ & $\mathbf{\%}$ \\
\hline $\mathrm{SA}$ & 10 & 11.2 & -1.2 & 1.44 & 0.1 & 17.9 \\
\hline $\mathrm{A}$ & 20 & 11.2 & 9.8 & 96.04 & 8.6 & 35.7 \\
\hline NO & 4 & 11.2 & -7.2 & 51.84 & 4.6 & 7.1 \\
\hline $\mathrm{D}$ & 18 & 11.2 & -6.8 & 46.2 & 3.6 & 32.1 \\
\hline $\mathrm{SD}$ & 4 & 11.2 & -7.2 & 51.84 & 4.6 & 7.1 \\
\hline $\mathrm{X}^{2}$ \\
21.5
\end{tabular}

$\mathrm{X}^{2}=21.5 ; \quad \mathrm{df}=4 ; \quad \mathrm{CV}=7.78 ; \quad \mathrm{P}<.05$

$\mathrm{H}_{\mathrm{o}}$ : Service Delivery is not affected by Lack of Public Awareness

$\mathrm{H}_{1}$ : Service Delivery is affected by Lack of Public Awareness 
Good Governance: A Step towards Promoting Positive Attitude...

In table 13, it could be seen that ten (10) respondents representing nearly eighteen percent $(17.9 \%)$ strongly agreed that service delivery is affected by lack of public awareness; twenty (20) respondents representing nearly thirty-six percent $(35.7 \%)$ agreed that service delivery is affected by lack of public awareness; four (4) respondents representing a little over seven percent $(7.1 \%)$ did not state whether service delivery is affected by lack of public awareness or not; eighteen (18) respondents representing a little over thirty-two percent $(31.1 \%)$ disagreed that service delivery is affected by lack of public awareness; and four (4) respondents representing a little over seven percent (7.1\%) strongly disagreed that service delivery is affected by lack of public awareness. Majority of respondents agreed that service delivery is affected by lack of public awareness. This is found to be statistically significant $\left(\mathrm{X}^{2}=21.5 ; \mathrm{df}=4 ; \mathrm{CV}=7.78\right.$; $\mathrm{P}<.050)$ which stipulates that we reject the null hypothesis which states that service delivery is not affected by lack of public awareness; and reject the alternate hypothesis which states that service delivery is affected by lack of public awareness. We therefore conclude that service delivery is affected by lack of public awareness. This underscores the need to inform the public that it is the right of each and every citizen to be served by the civil servants.

Table 14: Service Delivery Vs Sabotage

\begin{tabular}{|c|c|c|c|c|c|c|}
\hline OPINION & $\mathbf{O}$ & $\mathbf{E}$ & $\mathbf{O}-\mathbf{E}$ & $\mathbf{( O - E ) 2}$ & $\frac{(\mathbf{O}-\mathbf{E})^{\mathbf{2}}}{\mathbf{E}}$ & $\mathbf{\%}$ \\
\hline $\mathrm{SA}$ & 6 & 11.2 & -5.2 & 27.04 & 2.4 & 10.7 \\
\hline A & 21 & 11.2 & 9.8 & 96.04 & 8.6 & 37.5 \\
\hline NO & 11 & 11.2 & -0.2 & 0.04 & 0.0 & 19.6 \\
\hline $\mathrm{D}$ & 12 & 11.2 & 0.8 & 0.64 & 0.1 & 21.4 \\
\hline $\mathrm{SD}$ & 6 & 11.2 & -5.2 & 27.04 & 2.4 & 10.7 \\
\hline $\mathrm{X}^{2}$ \\
13.5
\end{tabular}

$X^{2}=13.5 ; \quad$ df $=4 ; \quad C V=7.78 ; \quad P<.05$ 
$\mathrm{H}_{\mathrm{o}}$ : Service Delivery is not affected by sabotage

$\mathrm{H}_{1}$ : Service Delivery is affected by sabotage

In table 14, it could be observed that six (6) respondents representing nearly eleven percent (10.7\%) strongly agreed that service delivery is affected by sabotage; twenty-one (21) respondents representing nearly thirty-eight percent $(37.5 \%)$ agreed that service delivery is affected by sabotage; eleven (11) respondents representing nearly twenty percent $(19.6 \%)$ did not state whether service delivery is affected by sabotage or not; twelve (12) respondents representing nearly a little over twenty-one percent $(21.4 \%)$ disagreed that service delivery is affected by sabotage; and six (6) respondents representing nearly eleven percent (10.\%) strongly disagreed that service delivery is affected by sabotage. Majority of respondents agreed that service delivery is affected by sabotage. This is found to be statistically significant $\quad\left(X^{2}=13.5 ; \quad d f=4 ; \quad C V=7.78 ; \quad P\right.$ $<.050)$ which stipulates that we reject the null hypothesis which states that service delivery is affected by sabotage; and reject the alternate hypothesis which states that service delivery is affected by sabotage. We therefore conclude that service delivery is affected by sabotage. This indicates that civil servants intentionally refuse to offer effective service delivery.

Table 15: HRM Vs Motivation

\begin{tabular}{|c|c|c|c|c|c|c|}
\hline OPINION & 0 & $E$ & O-E & $(O-E) 2$ & $\frac{(O-E)^{2}}{E}$ & $\%$ \\
\hline SA & 15 & 11.2 & 3.8 & 14.44 & 1.3 & 26.8 \\
\hline$A$ & 24 & 11.2 & 12.8 & 163.84 & 14.6 & 42.9 \\
\hline NO & 3 & 11.2 & -8.2 & 67.24 & 6.0 & 5.4 \\
\hline D & 7 & 11.2 & -4.2 & 17.64 & 1.6 & 12.5 \\
\hline SD & 7 & 11.2 & -4.2 & 17.64 & 1.6 & 12.5 \\
\hline $\begin{array}{ll}X^{2} & 25.1 \\
\end{array}$ & & & & & & 100.1 \\
\hline
\end{tabular}


Good Governance: A Step towards Promoting Positive Attitude...

$\mathrm{X}^{2}=25.1 ; \quad \mathrm{df}=4 ; \quad \mathrm{CV}=7.78 ; \quad \mathrm{P}<.05$

$\mathrm{H}_{0}$ : HRM is not affected by lack of Motivation

$\mathrm{H}_{1}$ : HRM is affected by lack of Motivation

In table 15 , it could be observed that fifteen (15) respondents representing nearly twenty-seven percent (26.8\%) strongly agreed that HRM is affected by lack of motivation; twenty-four (24) respondents representing nearly forty-three percent $(42.9 \%)$ agreed that HRM is affected by lack of motivation; three (3) respondents representing a little over five percent $(5.4 \%)$ did not state whether HRM is affected by lack of motivation or not; seven (7) respondents representing nearly thirteen percent $(12.5 \%)$ disagreed that HRM is affected by lack of motivation; and seven (7) respondents representing nearly thirteen percent $(12.5 \%)$ strongly disagreed that HRM is affected by lack of motivation. Majority of respondents agreed that HRM is affected by lack of motivation. This is found to be statistically significant $\left(X^{2}=\right.$ $25.1 ; \quad$ df $=4 ; \quad C V=7.78 ; \quad P<.050$ ) which stipulates that we reject the null hypothesis which states that HRM is not affected by lack of motivation; and accept the alternate hypothesis which states that HRM is affected by lack of motivation. We therefore conclude that HRM is affected by lack of motivation. This signifies the need to motivate civil servants.

Table 16: HRM Vs Lack of Satisfaction

\begin{tabular}{|c|c|c|c|c|c|c|}
\hline OPINION & 0 & $\mathbf{E}$ & O-E & $(O-E) 2$ & $\frac{(O-E)^{2}}{E}$ & $\%$ \\
\hline SA & 16 & 11.2 & 4.8 & 23.04 & 2.1 & 28.6 \\
\hline A & 24 & 11.2 & 12.8 & 163.84 & 14.6 & 42.9 \\
\hline $\mathrm{NO}$ & 3 & 11.2 & -8.2 & 67.24 & 6.0 & 5.4 \\
\hline $\mathrm{D}$ & 7 & 11.2 & -4.2 & 17.64 & 1.6 & 12.5 \\
\hline SD & 6 & 11.2 & -5.2 & 27.04 & 2.4 & 10.7 \\
\hline $\begin{array}{l}X^{2} \\
26.7\end{array}$ & & & & & & 100.1 \\
\hline
\end{tabular}

$\mathrm{X}^{2}=26.7 ; \quad \mathrm{df}=4 ; \quad \mathrm{CV}=7.78 ; \quad \mathrm{P}<.05$ 
$\mathrm{H}_{\mathrm{o}}$ : HRM is not affected by lack of satisfaction

$\mathrm{H}_{1}$ : HRM is affected by lack of satisfaction

In table 16, it could be observed that fifteen (16) respondents representing nearly twenty-nine percent (28.6\%) strongly agreed that HRM is affected by lack of satisfaction; twenty-four (24) respondents representing nearly forty-three percent $(42.9 \%)$ agreed that HRM is affected by lack of satisfaction; three (3) respondents representing a little over five percent $(5.4 \%)$ did not state whether HRM is affected by lack of satisfaction or not; seven (7) respondents representing nearly thirteen percent (12.5\%) disagreed that HRM is affected by lack of satisfaction; and six (6) respondents representing nearly eleven percent (10.7) strongly disagreed that HRM is affected by lack of motivation. Majority of respondents agreed that HRM is affected by lack of satisfaction. This is found to be statistically significant $\left(X^{2}\right.$ $=26.7 ; \mathrm{df}=4 ; \quad \mathrm{CV}=7.78 ; \mathrm{P}<.050$ ) which stipulates that we reject the null hypothesis which states that HRM is not affected by lack of satisfaction; and accept the alternate hypothesis which states that HRM is affected by lack of satisfaction. We therefore conclude that HRM is affected by lack of satisfaction. This signifies that despite government attempt of the recent increase in salary, civil servants are not satisfied.

Table 17: Expenditure Management Vs Lack of Accounting Knowledge

\begin{tabular}{|c|c|c|c|c|c|c|}
\hline OPINION & 0 & $\mathrm{E}$ & O-E & $(O-E) 2$ & $\frac{(O-E)^{2}}{E}$ & $\%$ \\
\hline SA & 10 & 11.2 & -1.2 & 1.44 & 0.1 & 17.9 \\
\hline A & 10 & 11.2 & -1.2 & 1.44 & 0.1 & 17.9 \\
\hline $\mathrm{NO}$ & 20 & 11.2 & 8.8 & 77.44 & 6.9 & 35.7 \\
\hline D & 12 & 11.2 & 0.8 & 0.64 & 0.1 & 21.4 \\
\hline SD & 4 & 11.2 & -7.2 & 51.84 & 4.6 & 7.1 \\
\hline $\mathrm{X}^{2}$ & & & & & 11.8 & 100.0 \\
\hline
\end{tabular}


Good Governance: A Step towards Promoting Positive Attitude...

$\mathrm{H}_{\mathrm{o}}$ : Expenditure Management is not affected by lack of accounting knowledge

$\mathrm{H}_{1}$ : Expenditure Management is affected by lack of accounting knowledge

In table 17, it could be observed that ten (10) respondents representing nearly eighteen percent (17.9\%) strongly agreed that expenditure management is affected by lack of accounting knowledge; ten (10) respondents representing nearly eighteen percent $(17.9 \%)$ agreed that expenditure management is affected by lack of accounting knowledge; twenty (20) respondents representing a early thirty-six percent $(53.7 \%)$ did not state whether expenditure management is affected by lack of accounting knowledge or not; twelve (12) respondents representing a little over twentyone percent $(21.4 \%)$ disagreed that expenditure management is affected by lack of accounting knowledge; and four (4) respondents representing a little over seven percent (7.1) strongly disagreed that expenditure Management is affected by lack of accounting knowledge. Majority of respondents agreed that expenditure management is affected by lack of accounting knowledge. This is found to be statistically significant $\quad\left(X^{2}=11.8 ; \quad d f=4 ; \quad C V=7.78 ; \quad P<.050\right)$ which stipulates that we reject the null hypothesis which states that expenditure management is not affected by lack of accounting knowledge; and accept the alternate hypothesis which states that expenditure management is affected by lack of accounting knowledge. We therefore conclude that expenditure management is affected by lack of accounting knowledge. This connotes that officers in the expenditure management require education and or training in expenditure management. 
Table 18: Expenditure Management Vs Lack of Accounting Skills

\begin{tabular}{|c|c|c|c|c|c|c|}
\hline OPINION & $\mathbf{O}$ & $\mathbf{E}$ & $\mathbf{O}-\mathbf{E}$ & $\mathbf{( \mathbf { O } - \mathbf { E } ) \mathbf { 2 }}$ & $\frac{(\mathbf{O}-\mathbf{E})^{\mathbf{2}}}{\mathbf{E}}$ & $\mathbf{\%}$ \\
\hline SA & 20 & 11.2 & 8.8 & 77.44 & 6.9 & 35.7 \\
\hline A & 10 & 11.2 & -1.2 & 1.44 & 0.1 & 17.9 \\
\hline NO & 10 & 11.2 & -1.2 & 1.44 & 0.1 & 17.9 \\
\hline D & 13 & 11.2 & 1.8 & 3.24 & 0.3 & 23.2 \\
\hline SD & 3 & 11.2 & -8.2 & 67.24 & 6.0 & 5.4 \\
\hline$X^{2}$ \\
13.4
\end{tabular}

$\mathrm{X}^{2}=13.4 ; \quad \mathrm{df}=4 ; \quad \mathrm{CV}=7.78 ; \quad \mathrm{P}<.05$

$\mathrm{H}_{0}$ : Expenditure Management is not affected by lack of accounting skills

$\mathrm{H}_{1}$ : Expenditure Management is affected by lack of accounting skills

In table 18, it could be observed that twenty (20) respondents representing nearly thirty-six percent (35.7\%) strongly agreed that expenditure management is affected by lack of accounting skills; ten (10) respondents representing nearly eighteen percent $(17.9 \%)$ agreed that expenditure management is affected by lack of accounting skills; ten (10) respondents representing nearly eighteen percent (17.9\%) did not state whether expenditure management is affected by lack of accounting skills or not; thirteen (13) respondents representing a little over twenty-three percent (23.2\%) disagreed that expenditure management is affected by lack of accounting skills; and three (3) respondents representing a little over five percent (5.4\%) strongly disagreed that expenditure Management is affected by lack of accounting skills. Majority of respondents agreed that expenditure management is affected by lack of accounting skills. This is found to be statistically significant $\left(X^{2}=13.4 ; \mathrm{df}=4 ; \mathrm{CV}=\right.$ 7.78; $\quad P<.050)$ which stipulates that we reject the null 
Good Governance: A Step towards Promoting Positive Attitude...

hypothesis which states that expenditure management is not affected by lack of accounting skills; and accept the alternate hypothesis which states that expenditure management is affected by lack of accounting skills. We therefore conclude that expenditure management is affected by lack of accounting skills. This implies that officers in the expenditure management require training in accounting skills.

\section{Findings}

* Reform program pays equal attention to all citizens

* Civil Service (HR) is ineffective

* HRM is affected by lack of motivation.

* HRM is affected by lack of satisfaction.

* Financial Regulations are violated in Government Expenditure.

* Expenditure management is affected by lack of accounting knowledge.

* Expenditure management is affected by lack of accounting skills.

* Service Delivery is poor in the Civil Service

* Service delivery is affected by lack of public awareness.

* Service delivery is affected by sabotage.

* Unethical Practices do exist in Civil Service.

* Ethics is more of theory than practice in the civil service.

* Ethics is more of practice than theory in the society.

* Top Management System is poor

* Top management system is affected by lack of training.

* Top management system is affected by lack of proper attitude.

\section{Recommendations}

* Civil servants need a lot more of education, training and development. The Ethiopian Civil Service College should be more empowered to undertake the 
education, training and development of the civil service. This could be achieved through development and delivery of new courses that are not offered in the universities.

* Universities and other tertiary institutions should emulate ECSC in developing their curricula by making the curricula customer based as well as marrying theory and practice in the curricula.

* Government should make some efforts to motivate the civil servants. Activities such as end-of-year party where high achievers are honoured should be instituted.

* Thorough training and development need analysis/assessment should be conducted by all organs of the civil service. Such activities should be monitored by the Federal Civil Service Agency.

* Government should enforce strict compliance to the TNA results. In this parlance, TNA officers should be appointed in all government institutions.

* Ethiopian Civil Service College and Ethiopian Management Institute should be required to offer trainings to designated TNA officers.

* Although, government has been paying adequate attention to the dissemination of information concerning the reform program, more effort should be made to further inform the public about their rights to be served by the civil servants.

* Although, some public offices are by their nature political, government should strive more to encourage professionalism. 
* At present more attention is paid to development rather than training. Hence, more attention should be focused on training the civil service in such areas as office procedures like report writing, minuting in files, minutes of meeting, memo writing, speech writing, handling official documents, security consciousness

* Civil Service needs to have its own language, vocabulary and jargons like any other profession. This would give unity of direction in communication.

\section{Conclusion}

What we have tried to show in this paper is that there is synergy between government reform and good governance. If good governance should strive, then the reform programme must succeed. It is the premise of this paper that sustainable national development is dependent on good governance and good governance is dependent on effective, efficient and economic civil service that is transparent, accountable and responsive to the yearnings of the public.

Our work in this paper suggests that good governance includes such elements as effective civil service, ethical civil service, service delivery oriented civil service, coordinated top management system as well as appropriate expenditure management and control. 


\section{References}

Ayeni, V. (2000). Developing Administrative Institution for

Good Governance:Recent Experience and Future Prospects. Nairobi: AAPAM

Federal Democratic Republic of Ethiopia (2006/7). Civil Service Reform Documents

Sambo, B. I. (2004). Management and Behaviour in Organizations. Badagry, Lagos: ASCON Ventures Services

The United Nations Development Programme (UNDP) The World Bank (1998). Good Governance in Developing Eco 